\title{
How Corporate Social Performance Is Institutionalised Within the Governance Structure
}

\author{
Frank J. de Graaf \\ Cor A. J. Herkströter
}

The Dutch Corporate Governance Model

\begin{abstract}
Since Ackerman in Corporate social responsiveness, the modern dilemma (1973), pleaded for the institutionalisation of corporate social performance (CSP) in business processes, researchers have focused on the role of strategy in CSP. This article demonstrates that CSP is institutionalised within the governance structure. We will attempt to make this clear by means of a description of the Dutch system of corporate governance. Under certain circumstances Dutch companies are already bound to CSP due to prevailing legislation. A governance perspective shows that CSP is institutionalised within a company's governance structure. "Processes of responsiveness", since long regarded as a starting point of CSPanalysis, appear to be decision-making processes. Within these processes the expectations of the stakeholders can be institutionalised, trust can be built and interests can be incorporated. This makes CSP context-dependent. However, it is possible to analyse companies by comparing the companies' individual governance structures. The article concludes that CSP-analysis can fruitfully extend into analysing in the role of the stakeholders in the influence-pathways that are incorporated within the governance structure.
\end{abstract}

KEY WORDS: corporate governance, corporate social performance, stakeholder influence

Dr. Frank Jan de Graaf is researcher at the University of Amsterdam Business School and Adviser Responsible Investment at PGGM Investments.

$\operatorname{Cor}$ A. J. Herkstroter is holding the chair International Management at the University of Amsterdam Business School.

With gratitude to Aime Heene, Nikolay Dentchev, Matthew Haigh, Harm Jan de Kluiver, Jonatan Pinkse, Bas Steins Bisschop and two anonymous reviewers.

\section{Introduction}

There is a growing interest in the relationship between corporate governance and the social performance of a company. Literature focuses specifically on the composition of the board (Coffey and Wang, 1998; Luoma and Goodstein, 1999), emphasises the practical implications of certain theoretical assumptions (Leader, 1999) or studies the institutional embeddedness of companies (Heath and Norman, 2004). This study analyses the influence of pathways that stakeholders and companies use to balance specific interests and thereby shape the social performance of a company. It demonstrates the influence-pathways that can be - and sometimes have been - constructed by a company and stakeholders to institutionalise certain social responsibilities. These insights are produced in a description of the institutionalisation of corporate social performance (CSP) in the Dutch system.

In the literature, CSP is defined as "a business configuration of principles of social responsibility, processes of social responsiveness, and policies, programmes, and observable outcomes as they relate to the firm's societal relationships" (Wood, 1991, p. 693).

A researcher or manager who theoretically or practically wishes to implement CSP, therefore, faces challenges if attempting to create effective links between these concepts. In corporate processes, the principles of the company, stakeholders and the corporate policies meet. Ethical values are shaped within the interaction with stakeholders and transformed to policies, where the outcomes of certain policies influence ethical values and stakeholder expectations again. This article proposes that in such a conceptual model the governance structure will play a major role. 
Readers of Ackerman's article How companies respond to social demands (1973) will recognise the theoretical building blocks which by now have become standard elements in the theoretical discussions on CSP, but which also have become widely accepted in business administration. Ackerman (1973) asserts that a company's CSP is not limited to good intentions of the management. CSP must be institutionalised within the business processes and anchored within society.

In a later publication, Bauer and Ackerman (1976) enunciates that "responsiveness", 1 or, a company's willingness to accommodate social developments, would be an appropriate start of analysis. The social responsibility of a company is constituted in the interaction between the company and the stakeholders. From this observation Bauer and Ackerman (1976) conclude that one should not so much refer to corporate social responsibility - the social responsibility of a company - as to corporate social responsiveness, or, the willingness to bear the responsibility for certain prevailing expectations in society.

The notion introduced by Bauer and Ackerman (1976) did not meet with widespread acceptance. Yet, a "company's responsiveness to social developments" has been regarded as the starting point of CSP-analysis since (e.g. Carrol, 1979; Margolis and Walsh, 2003; Wartick and Cochran, 1985; Wood, 1991).

Wartick and Cochran (1985) elaborate upon the notion's process-related character. According to them, a company's responsiveness to its environment is not a static aspect. Instead, the argue, CSP relates to a continuous interaction between stakeholders interested parties on whom a company's future existence is (co-)dependent - and the company itself. It relates to "processes of responsiveness" in which the company has an own identity. Yet, it cannot determine what is important without the stakeholder inputs.

The process approach of Wartick and Cochran (1985) is detailed by Wood (1991). Not only is the interaction between a company and its environment important. While an interaction between norms and values of a company, as is formulated in the principles of corporate social responsibility, and the policy resulting from these norms and values, is also significant. Wartick and Cochran (1985) still hold to a responsibility with a standardised formulation that is the same for all companies. Wood (1991) asserts that corporate social responsibility is established by means of interaction. At a certain moment, a company will define what it sees as its own responsibility. At times it might be formulated explicitly. Yet, quite often it consists of the patterns of expectation which stakeholders have towards one another and towards the company. These expectations, which may be traced back to norms and values, develop within the "processes of responsiveness", eventually leading to social policies, social programmes and social impacts (Swanson, 1995, 1999).

Berman and Rowley (2000), having completed a literature review, regretfully observe that CSPanalysis has not advanced much beyond a clarification of the concept. Some research was been done, but had been hampered by the researcher's objective in wanting to prove that CSP was an important development. Therefore, together with other researchers, Berman and Rowley (2000) plea for more descriptive and inductive research (see also Griffin, 2000; Margolis and Walsh, 2003). Further development of the theory has to stay as close to business practice as possible. With this objective, we follow the pragmatist's approach, advocated by Margolis and Walsh (2003, p. 283). In pleading for a reorienting perspective on the theory of the firm, descriptive research strategies are necessary again, because 30 years of CSP-research has not managed to overcome critical flaws.

By building on CSP theory, the article demonstrates that the governance structure of a company can play an important role in the interaction between a company and stakeholders, the "processes of responsiveness". Since Ackerman (1973) researchers' attention has been mainly focused on company strategy (Wood, 1991). Below, it is argued that the stakeholders may structurally exercise control over a company by their position towards the company's management as it is defined in the governance structure. In this paper we attempt to mirror business practice as accurately as possible by describing the role of the institutional environment in which companies' operation. Analysis of the governance structure makes it possible for the researcher, consultant and manager to understand the processes that embody CSP, so that the concept can successfully be made operational. This furthermore develops insights on how stakeholders can be represented in the networks in which a company operates (Leader, 
1999) and also how stakeholder-learning-dialogues are shaped in existing governance systems.

By making this statement, the paper focuses strongly on the position of the employees in Dutch corporations and by the formal regulation that give them a position in the governance structure. However, if - besides shareholders - one group of stakeholders can have a formal position, others could acquire a comparable position. For example, within cooperatives stakeholders unite to fulfil a specific economic need. Clients, for example within cooperative banks, or suppliers, often in the agricultural sector, thereby have a critical role in the governance structure also.

\section{CSP and corporate governance}

Analysis of corporate governance yields important insights to researchers and managers involved in CSP. The general assumption is that the interaction between the stakeholders and a corporation forms the starting point for CSP-analysis (Bauer and Ackerman, 1976; Berman and Rowley, 2000; Swanson, 1995, 1999). In order to implement CSP a company has to have a good insight in its environment. In order to reach this insight, Wood (1991) defines three policy instruments: stakeholder management, issue management and environment analysis. She uses these tools to create a functional description of the "processes of responsiveness". Management mainly determines the responsiveness of a company to social developments.

Corporate governance literature reveals yet another perspective aside from these three policy instruments. Luoma and Goodstein (1999, p. 554) argue that, if we assume that company's attention to the social interests of stakeholders is regarded as important and legitimate, it may also be assumed that this is institutionalised in social structures, especially in corporate governance. For researchers of CSP it is important to analyse the relationship between the position of stakeholders within the company management and the processes and performance of a company (p. 561). Slowly, empirical research, which studies this relationship, is published. However, the results are not (Coffey and Wang, 1998; Hillman et al., 2001) unambiguous. Some further theoretical development on this matter seems to be of great value.
By means of their position in the governance structure, stakeholders structurally influence company policy. The governance structure is the sum total of all formal procedures and processes in which decisions are made (Nooteboom, 1999; Williamson, 2000). Responsibilities are institutionalised in the corporate governance structure. If, for example, a company has to submit decisions to a works council then this may influence the decisions. This concept will be elaborated below.

The governance structure is the result of the company's characteristics, its identity and of the demands imposed on the company by the stakeholders and by the law and regulations as imposed by the authorities. The governance system may be defined as the legal framework within which the relationship between stakeholders and a company may be constituted ${ }^{2}$ (Weimer and Pape, 1999; Whitley, 1999). This legal framework, largely determines which structural influence stakeholders do exercise on company policy within the governance system. The governance system, itself however, is also determined by the influence stakeholder groups have (had) on society.

The opinions on governance systems differ per theory and per national context. Authors such as Freeman and Reed (1993), Kochan and Rubinstein (2000) and Davis et al. (1997) argue for a stewardship or stakeholder model for corporate governance. In this theoretical conception it is stated that the company must not only be accountable to the shareholders as is the rule in the Anglo-Saxon nations. A company is a type of stakeholders' association.

The stakeholder perspective of a company supplements the agency theory, which is so prevalent in business economics and management science. The agency conception is based on the conflict of interests between the shareholder (principal) and the manager (agent). Critics of the agency theory propose that too much emphasis is placed on the conflict of interest between rationally operating actors, which is between the managers and the owners of a company, the shareholders.

Insights concerning the role of a company's governance structure may contribute to research and policy making in the field of CSP. The interaction between a company and its stakeholders is largely institutionalised in the governance structure. 
Therefore, the company structure must fulfil a role within academic CSP-analysis and in the policy making of governments and companies. The shape of this structure in a certain national context mainly determines how and when stakeholders influence a company's policy. With the choice of this perspective, we make a fundamental choice regarding the form of CSP-analysis. It is not an additional policy area for companies. The corporate social responsibility is being institutionalised within the corporate governance structure. Researchers are mainly interested in the question how companies accommodate developments going beyond the imposed limited economic, legal and technical demands.

\section{CSP and the national governance system}

As some of the authors with this view, Kochan and Rubinstein (2000) refer to the governance system as it exists in continental Europe and Japan in their plea for the stakeholder perspective of a company. These systems are network-oriented (Moerland, 1995; Nooteboom, 1999; Weimer and Pape, 1999). The collaboration amongst the various stakeholders is essential. According to researchers such as Freeman and Reed (1993), it is the lack of collaboration in the governance systems in Anglo-Saxon nations which lead to the search for alternatives. The American and Anglo-Saxon system may be categorised as marketoriented with its emphasis on the financial market and, primarily, on the shareholder seeking a return on his investment (see Table I). In a company, the expectations of the stakeholders are largely institutionalised within the governance structure.

In the governance structures in the United States and even more in the United Kingdom, expectations of the financial markets (market-oriented) are more prominent. Much attention is given to the shareholders' position, both regarding their involvement as well as regarding the supply of information. The wider social interest must mainly be protected by (governmental) regulations. In this constellation, company and stakeholders enter into short-term relationships that are broken as soon as one of either party is given a more interesting offer. Due to the stakeholders' focus on their own interest, the governance system in the United States is based on laws and regulations more than it is in Europe (Nooteboom, 1999). Suitable recent illustrations of this phenomenon are the

TABLE I

The characteristics of governance systems

\begin{tabular}{|c|c|c|}
\hline Governance system & Market-based & Network-based \\
\hline \multirow[t]{3}{*}{ General characteristics } & Market orientation & Internal orientation \\
\hline & Short-term relations & Long-term relations \\
\hline & Competition & Cooperation \\
\hline Governance structure & $\begin{array}{l}\text { Capitalist form, focus on the } \\
\text { financial markets, the shareholders }\end{array}$ & Collective form, focus on a group of stakeholders \\
\hline Forms of corporate control & $\begin{array}{l}\text { Exit-based, when } \\
\text { dissatisfied, stakeholders leave }\end{array}$ & $\begin{array}{l}\text { Voice-based, when dissatisfied, stakeholders } \\
\text { complain in the network }\end{array}$ \\
\hline Governance mechanism & Contract & Trust \\
\hline Governance evaluation & Third parties & Networks \\
\hline Theory & Agency theory & $\begin{array}{l}\text { Stewardship theory/normative } \\
\text { stakeholder theory }\end{array}$ \\
\hline Research orientation & $\begin{array}{l}\text { Agency problems between the } \\
\text { management and shareholders }\end{array}$ & Balancing stakeholder interests \\
\hline Countries & United States and Great Britain & Continental Europe and Japan \\
\hline $\begin{array}{l}\text { Stakeholder } \\
\quad \text { influence strategies }\end{array}$ & $\begin{array}{l}\text { Emphasis on indirect } \\
\text { influence-strategies }\end{array}$ & Emphasis on direct influence-strategies \\
\hline $\begin{array}{l}\text { Characteristics of stakeholder } \\
\text { influence-pathways }\end{array}$ & Regulation & Consultation \\
\hline
\end{tabular}


reactions to the financial scandals in business. The Dutch corporate governance code imposes general demands on companies. Companies may even ignore certain measures if they motivate their approach with the proper reasons. In the United States the response was to create more detailed legislation. The SarbanesOxley Act was adopted for example.

The Anglo-Saxon practice, therefore, differs quite substantially from the Dutch governance system. Within the Dutch, network-oriented system, the supervisory board controls the executive board. The preservation of the company's continuity is an important element in this respect. In view of this broader responsibility the supervisory directors have a task, which exceeds the individual interests of a single group of stakeholders. The works council and the shareholders meeting may only nominate the members of the supervisory board. This Dutch variant was chosen so that no single stakeholder eventually might exercise decisive influence in the company. Collaboration for a long-term and the continuity of the company are at the core of the Dutch network-oriented system.

We can mark the starting point of our analysis with the conclusion that national governance systems could largely determine company policy. It is important to look at how a company has responded to a structural, social development and what the role of the corporate structure was in this respect. This may be different for each national context. Even differences within the governance structure per individual company are important in the design of social corporate governance.

\section{Two forms of influence}

Now that we have been able to determine that the governance structure plays an important role within the interaction between a company and stakeholders in the national context, it is important to examine the way in which a company and stakeholders mutually influence one another. Even the influencing processes may differ per governance system.

There are two forms of influencing by stakeholders (Frooman, 1999; Gargiulo, 1993). First, stakeholders may directly influence a company, for example, by entering into negotiations on policy issues. Second, stakeholders possess indirect influence-pathways. It is a case of indirect influence when stakeholders attempt to convince a third party to represent their interest. In certain cases, this third party may exercise more influence in the company than the individual stakeholder.

Direct and indirect influence-pathways are also evident within governance systems. Primarily, stakeholders may directly influence a company because they possess a (formal) voice in company policy. In network-oriented systems of corporate governance, as they exist in Europe and Japan, the emphasis has always been on this kind of influence (see Table I). Most Dutch companies have adopted the objective to consider the interests of clients, shareholders and employees in their policy. All of the concerned parties are also co-responsible to safeguard the social interest in the company. Metaphorically speaking, employees, shareholders and clients attend the board meeting.

A second form of influence consists of indirect influence-pathways. With the help of third parties, such as supervisory bodies and the government, stakeholders may influence decisions. Regulations serve, for instance, to protect the stakeholders' interests. The government and supervisory bodies are responsible for the quality of these regulations and they check whether the regulations are observed. When there is a threat of opposing interests between a stakeholder and a company parties will examine their options by looking at their legal position. If a court case might improve their position they may decide to initiate it.

Even non-governmental organisations such as environmental groups often make use of such indirect mechanisms. Via the media or via the court they attempt to obtain attention for a certain matter in order to persuade a company to change.

In market-oriented systems of corporate governance - e.g. in the United States ${ }^{3}-$ the emphasis is on this form of influence. The government is primarily focused on protecting a properly functioning market. The government limits its role in the structuring of the negotiations between company and stakeholders to guaranteeing the shareholders' influence. The administration of justice is important in handling the conflicts of interests between stakeholders and companies.

In Anglo-Saxon systems as well as in European systems both forms of influence play a role. It is 
especially the emphasis on influence-pathways that makes the systems different. This emphasis is partly determined by culture. A Dutch stakeholder may, perhaps go to court over a certain matter. Yet, primarily, he will attempt to solve a conflict of interest by negotiations. Dutch law obligates him to do so. Cultural characteristics such as the emphasis on negotiations and the seeking for a common basis for agreement have been institutionalised in the prevailing regulations. A description of Dutch law concerning corporate governance may shed light on this.

\section{A closer look at the Dutch governance system}

The implications of a governance perspective of CSP are discussed in this paragraph. We do this by describing the development within the Dutch corporate governance system. We describe how social interests and the stakeholders' interests are institutionalised. It will become evident that the demands on and the expectations of corporate governance are primarily determined by the institutional context. The reciprocal influence between company and stakeholders is shaped in mostly subtle governance mechanisms. Within Dutch company law the demands imposed on corporate governance are laid down in the Structure Act that was passed in 1971. In the light of the current discussion on corporate governance in The Netherlands, in which the position of the shareholders is given much attention, it is striking that the principle of the Structure Act was to find a solution for employee participation in The Netherlands. In the works council, the employees were given a voice in company management. The establishment of the works council was also regulated by the Works Councils Act adopted by the Dutch parliament in 1971.

The Structure Act was the result of a broad social discussion in The Netherlands. In the 60s the socalled Verdam Committee had indicated three reasons why the existing legislation had to be amended:

1. It appeared that in practice, the role and the interests of the capital supplier were not exclusively the leading factor in corporate policy.

2. The companies' striving for profit for the benefit of the shareholders was an insufficient justification to withhold influence from the other stakeholders.

3. There was a nationwide social discussion about the role of the "factor labour" (the employees), which demanded a response from the legislature. In this discussion primarily the pleas for employees' self-governance received much support, although there was also some harsh opposition from employer-related groups.

The Structure Act (see Figure 1) has been referred to as the "miracle of The Hague". Labour and capital were reconciled with one another in a time in which they had opposing positions in the public debate and in which companies were regarded with suspicion. For a long time no agreement seemed possible in the social debate. Companies strongly resisted the farreaching influence of the employees as advocated by politicians and trade unions.

In the act the (suggested) contrary interests of labour and capital were bridged by giving the supervisory board ${ }^{4}$ a key role to play. They became responsible for the adoption of the annual accounts, the supervision of the general strategy and for the appointment of the members of the executive board and of the supervisory board. This latter ingredient meant that the composition of the board of supervisory directors was the result of co-option. The current members determined who was newly appointed in the board. Shareholders and employees were only granted options to recommend new members of the supervisory board and to object to a

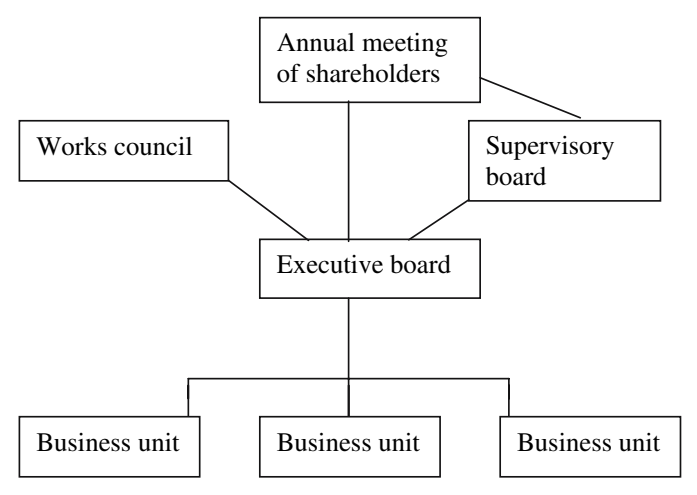

Figure 1. The governance structure according to the Dutch Structure Act of 1971. 
proposed candidate. Again, a power balance was developed carefully, between various stakeholder interests. Interests in developing subtle influencepathways. Stakeholders have influence on the supervisory board, and it is difficult for the board to overrule them, but when stakeholders put too much pressure on the board to advocate their interests, the board has its own legal obligations to stand for the companies' interests.

With the Structure Act the works councils were given a special place in company law. The fact that they could nominate supervisory directors was supplemented by clauses in the Works Councils Act. Due to this act, the works council received three other rights (1) the right of information, (2) the right of advice and (3) some decisions depend on its approval. The last-mentioned right relates to decisions regarding reorganisations, investments and changes affecting the legal status of all employees. After 1971 the works council's position was reinforced. The law was amended a number of times and the role of works councils became a topic of case law.

One of the last modifications of the law was the supplement of Article 28 of the Works Councils Act in 1998 (see Appendix 1). This states that the works council may give advice on social subjects and on the company's sustainability policies. Due to this amendment, social policy and social sustainability became a company objective. The works council had to supervise the safeguarding of these principles. Thus, (again) its broad social responsibility was reinforced. No longer did the works council only safeguard limited employees' interests.

This right of advice is important, which demonstrates how subtle the role of stakeholders in influencing the pathways can be. The management may not treat an advice of the works council as a mere formality. Company managers have to ask for advice at such a term that it is possible for the works council to exercise its influence on the decision. If the works council is able to prove that the company management did not listen to it before the decision was made then the works council may take the matter to court. The judge may, as long as the procedure is pending, fully or partially revoke the decision and cancel any consequences. If the management rejects an advice then the company management has to make clear that the advice was seriously considered and give a proper motivation for its rejection.
It may be concluded that the Dutch system of corporate governance wants to guarantee a proper interaction between the company and the stakeholders. Moreover, legislation decrees that a company represents a broader social interest and not merely an economic interest. The environmental and social issues are mentioned explicitly in this respect. Aside from the supervisory board the works council has a task in the execution of the broader social responsibility.

Against this backdrop, it is understandable that in 1999 the Social Economic Council (SER) - an advisory body of the Dutch government, with representatives for employees, employers and independent members - created an advisory report that no additional legislation concerning the field of CSP is needed in The Netherlands for the time being. For this had already been incorporated in the law. In its report De winst van waarden ${ }^{5}$ the SER uses a definition of socially responsible business ${ }^{6}$, which is in the line of the legal obligations of a company. CSP is regarded as both the interaction between stakeholders as well as the broad social responsibility of a company (SER, 2000 , p. 13). With its report the SER once again confirmed the stakeholders' shared responsibility for the company's continuity.

\section{CSP and stakeholders' influence}

\section{Anchoring of CSP}

The development in Dutch company law reveals how a company's social role has been anchored and what the role of the stakeholders is. Dutch legislature has defined this influence in several ways:

- Some stakeholders exercise influence on company policy. This defines the interactive character of CSP.

- Stakeholders have a joint responsibility to monitor the consequences of company policy for the environment and the social conditions of the concerned parties.

The stakeholders' role can be based on the Structure Act and the Works Councils Act and it is in 
agreement with the CSP definition. Interaction with stakeholders and a broad social responsibility are the key elements of CSP (see definition on page 2). The responsibility is defined and the interaction between stakeholders and a company is structured. In the meantime, legislature has also taken an interest in what companies "do", e.g. in the reporting of performances. A further analysis of the way in which the Dutch legislature directed both the social responsibility as well as the influence processes of stakeholders makes clear why it is so important that these have been formulated in a general sense.

\section{Stakeholders' influence in Dutch corporations}

A main principle of the Dutch legislation is that the legislature does not want to, and cannot, impose all social demands on a company. Especially in the
Dutch governance system, which is networkoriented, restraint is an important principle. Social responsibility cannot only be defined in rules. This means that a company and its stakeholders recognise a broader responsibility than their own, limited selfinterest. This responsibility is institutionalised in opportunities for participation. Opportunities for discussion and participation - often also imposed by legislation - supplement the demands that are imposed on company policy.

The broad responsibility is expressed in an often quite subtle interaction between various influencepathways (see Table II). These are partly a product of legislation yet often also based on agreements between stakeholders and a company. It relates to direct influence-pathways in which discussion and dialogue are important. These instruments are more flexible and interactive than regulations (Grandori, 1997; Nooteboom, 1999). The stakeholders and company are expected to work on a stable

TABLE II

Examples of direct and indirect influence-pathways

Direct influence-pathways

Annual meeting of shareholders

Meetings of company

representatives with analysts

Meetings with stock exchange authorities

Meeting with works councils

Meetings with labour unions

Performance interview

(Negotiations on) nomination and appointment of supervisory directors

Committees of the supervisory board

Consulting supervisory authorities

Client association

Customer association

Board of a cooperative

Negotiations with (major) clients and other meetings with clients (panels)

Negotiations with governments

Negotiations with and in branch associations
Indirect influence-pathways

Government regulation, statutory arrangements and regulation of supervisory authorities

Share price

Regulation of the stock exchange

Regulation (Works Councils Act, Structure Act), internal regulation, statutory arrangements and other

Report of the Works

Council in the annual report

Agreements on working conditions, other agreements, labour laws

Employment contract

Profile of the external directors, screening by supervisory authorities

Corporate governance policy, regulations by governments, reports presenting the advice of committees regarding corporate governance

Regulations and supervision

Influence-pathways can be institutionalised in the articles of association of the company

Articles of association of cooperatives, legislation regarding cooperatives

Contracts and other agreements

Regulations and other agreements

Covenants and other agreements 
relationship based on mutual trust. Only then both parties can be useful one to another.

Stakeholders and a company may together decide whether they want to anchor this responsibility even legally, for example in the articles of association please refer to examples of this in Appendix 2. Articles of association are usually put in such a way that they offer maximum managerial freedom. Yet, theoretically, it is possible that stakeholders modify these statutory objectives or that they challenge a company if, in their opinion, the principles embodied in the articles of association are insufficiently reflected in company policy. This may occur in the meeting of shareholders. Yet, even employees, government and supervisory bodies may exercise influence. It is an example of direct influence when stakeholders are able to amend the articles of association. It is an example of indirect influence when stakeholders take an issue to court if there is a discrepancy between the principles laid down in the articles of association and the actual policies.

\section{Defining responsibilities in influence-pathways}

A description of the Dutch governance system shows that a company's social responsibility may be defined in two ways.

First, the stakeholders may claim their position in the legal structure if they think that one of their interests is threatened. In order to increase the power of their protest they can take their case to court. Both shareholders as well as employees are entitled to do this. In such a situation it is a matter of indirect influence. A third party, able to exercise more power in a domain, is committed to protect the stakeholders' interests. The advantages of indirect influence-pathways are, amongst other things, that they offer a greater amount of legal certainty and that the rights and duties can be clearly formulated. The disadvantage is that regulations may be inflexible and the concerned parties may have the tendency to seek for loopholes (Grandori, 1997; Nooteboom, 1999).

Second, stakeholders may exercise influence by making use of direct influence-pathways. Bodies such as the shareholders meeting (of limited liability companies), the members meeting (of cooperatives) and the works council are such mechanisms. Direct influence-pathways seem to be more flexible than indirect mechanisms determined by regulations. Another advantage is that arrangements can be made to which every stakeholder agrees. The disadvantage is a more restricted legal certainty. Works councils have often remedied this by making extensive agreements and covenants with the company's executive board.

Attention for the first form of stakeholder influence sheds a new light on CSP policies. As stated before, it is essential in this respect that companies have to be responsible for more than the mere adherence to the regulations. This can be achieved by looking at the opportunities for involvement. In this context more normative and cognitive processes play a role in which norms and values are embodied before they are directly transformed into regulations.

\section{Dynamics in stakeholder influence}

A governance perspective of CSP also teaches us about the structure of stakeholder influence. The position of employees has been further expanded after the launch of the Works Councils Act. Employees had been given a formal position by the Works Council Act. It offered the opportunity to further develop rights, also in view of the development of case law regarding the status of the works council within a company.

Based on the theoretical perspective above, the question is whether the recourse to legal action in the relationship between the works council and company management has not been gained at the expense of either party's opportunities of implementing a broader social responsibility. The works council has various direct influence-pathways available for its operation. Proper consultation and open dialogue are quite important in this respect. The recourse to legal action may obstruct this open consultation process since the related parties are continuously checking the legal validity of statements.

During the past 15 years, the one-sided attention for the employee's status in legislation has evoked a counter movement in the Netherlands. Many shareholders are of the opinion that their influence on company policy is too small. In all possible ways, shareholders attempt to influence companies, supervisory bodies and the government to create more space for them. In such instances shareholder 
representing groups continuously seek media exposure and take legal action. These indirect influence-pathways are utilised since the direct influence-pathways have proven ineffective according to the concerned parties. The shareholders meeting, an example of a mechanism in which direct influence is feasible, offers the shareholders insufficient means to cause the company management to change its course. Social pressure - in a small country as the Netherlands often peer-group control (Moerland, 1995; Nooteboom, 1999) - will probably lead to the fact that shareholders obtain a better grip on corporate governance.

\section{Concluding remarks}

The interaction between a company and its environment is often seen as the starting point for CSPrelated analysis. The interaction between parties can be studied by means of an analysis of the influencepathways as defined within the governance structure. By hooking stakeholders on to the governance structure of the company, the social values that these stakeholders represent, are hence taken into account. Values, norms and expectations are evident in the structure of influence processes. It is useful to look at such processes when assessing the social performance of an individual company. These processes define the recognised responsibility and position of the company and its stakeholders.

Empirical research in CSP has focused on the determination of indicators by means of which the outcome of company policy can be assessed. Margolis and Walsh (2003) show that it has led to many conflicting studies without an attendant development in CSP theory. A governance perspective offers the opportunity to not only study policy content but processes in which CSP is shaped also. This makes it possible to study the institutionalisation of CSP, a long-standing research objective (Ackerman, 1973; Berman and Rowley, 2000; Margolis and Walsh, 2003). CSP is institutionalised by "organising" whose interest is taken into account within decision-making processes. This is done by structuring direct and indirect influence-pathways.

This increasingly gives empirical evidence for how stakeholder-learning-dialogues are developed within a governance system (Daboub and Calton,
2002) and how trust can be build in organisational governance (Caldwell and Karri, 2005). The Dutch case supplies proof of Caldwell and Karri's (2005) plea for building trust in economic systems by developing a stewardship model of the firm.

Adopting a governance perspective on CSP, enables deeper insight into the role of the basic assumptions or principles of a company. Some view a company's code of conduct as reflecting the principles of CSP (Swanson, 1995, 1999; Wood, 1991). A governance perspective reveals that the basic principles in which social responsibility is defined are anchored in a host of other procedures and processes, which are mainly to be found in the governance structure. This structure also relates the company to the governance system; the second area in which corporate social responsibility is institutionalised.

To illustrate, responsibilities as defined in the articles of association, provide a good starting point for analysis. Even the opportunities for participation of stakeholders are important in the formation of the basic principles for company policy and are institutionalised in company policy via direct and indirect influence-pathways. The role of formal instruments such as articles of association and participation deserve more attention in CSP-analysis.

Such subsequent analysis may also be relevant to the daily practice in companies. Currently, companies are facing questions of how they may make certain that employees act in an ethically responsible way and how they can adjust their actions to the environment. The problem in this context is that rules fall short. Employees' actions cannot be completely defined in regulations since this would work at the expense of their individual responsibility (Bovens, 1998).

Insight in the influence-pathways may lead to a different manner of handling ethical questions and social dilemmas, as suggested by various authors (Caldwell and Karri, 2005; Daboub and Calton, 2002; Leader, 1999; Zadek, 1998). Instead of regulations for actions, it turns out that the dialogue with stakeholders may take shape in the governance structure. Upon mutual consultation, a basis may be found for trust, which makes a solution possible that is acceptable to the company and the interested parties. It does not only define how a company must behave itself, it also defines when a company must involve the stakeholders in company policy. It is not 
so much the rules for action, but the rules for stakeholder interaction that institutionalise ethical behaviour.

The network system of corporate governance as operating in the Netherlands, amongst other nations, shows examples of these forms of stakeholder dialogue. In Dutch business, the shareholders, clients and employees exercise their influence in various ways, within the governance system and the governance structure. This can result in dialogues that are based on these positions. They even go further. Covenants, for example, are made between the companies and stakeholders (the government) to jointly develop new policy and change behaviour. Often, these covenants cannot be enforced legally. Therefore, mutual monitoring is extra important. Yet, trust is just as important. The joint responsibility for policy is accepted and in a dialogue the principles for the implementation of the policy are determined.

When influence-pathways are taken into account in CSP-analysis, the problem of stakeholder representation in the decision-making processes can be effectively addressed. In the Netherlands, the works councils in their current form have existed for over 30 years. A study of their influence on CSP operation might provide insight in the opportunities and problems that exist to involve large and extremely diverse groups in company policy.

Future research on how CSP is institutionalised in the governance structure should go further than regulation and the position of employees in a company. Other, more "voluntary" agreements also exist within organisations, for example in cooperatives where clients or suppliers have a critical role.

Major lessons can be drawn from this for the relationships with clients, shareholders and interest groups. Critics state that the current debate on greater influence for the shareholders has lead to more and sometimes counterproductive regulation. This may be counteracted by looking at how direct influencepathways - in which trust plays a major role - may be improved. A stakeholder committee, in which clients, shareholders as well as employees are represented, can play a role in this. The committee might make recommendations for who are important to the company and how they might be involved in company policy.

Finally, we should mention a number of major limitations of a governance perspective of CSP. The perspective as presented in the current paper has a focus on formal influence-pathways and processes. Informal processes are not dealt with even though these might be at least as important. Processes might be neatly arranged on paper. Yet, in practice, they might not be effective.

Moreover, this article deals with the importance of the national context. Yet, more and more companies operate in several countries. Thus, many Dutch companies have major interests abroad. The analysis perspective described here takes this only partly into account.

\section{Notes}

1 The word "responsiveness" is derived from "responsibility". "Responsiveness", therefore, means "to be willing to be responsible for...". Thus, the concept has strongly normative overtones (Bovens, 1998; Swanson, 1995).

2 This system goes beyond the governmental laws on corporate governance. It also relates to legislation in the field of supervision and other regulations protecting the stakeholders e.g. by legislation which organises consumers' rights. Another Dutch example is that of the supervision of various economic sectors in The Netherlands as it is organised in commodity boards. These independent bodies operate within the legal framework prescribed by the government and are managed by employers' and employees' representatives.

3 Aside from the Federal Government, the States exercise a primary role in the formation of governance systems in the United States. Therefore, here we talk about governance systems. Per State there are differences in the regulations.

4 Dutch companies' mainly operate in a two-tier board system, with an executive board and an independent supervisory board.

5 Lit. 'The return on values', translator.

6 The SER refers to social business, yet it explains the concept in the sense that the term CSP may be utilised.

\section{Appendix 1}

Article 28 of the Works Councils Act (WOR) since 1998

1. The works council promotes, as much as within its powers, the observance of all regulations that apply to the company in the field 
of the employment conditions, as well as the regulations in the field of the employment conditions and times for work and rest of the personnel employed within the company.

2. The works council, moreover, promotes according to its powers the work progress meetings, as well as the transfer of authority within the company, so that the persons employed within the company may be involved as much as possible in the regulation of the employment in the section of the company in which they are employed.

3. The works council in general guards against discrimination within the company and particularly promotes the equal treatment of men and women as well as the hiring of the handicapped and minorities in the company.

4. The works council promotes, according to its powers, the company's care of the environment, including which the creation or modification of facilities, be they policyrelated, organisational and administrative, in relation to the environment.

\section{Appendix 2: The broad social objective of companies is defined in the articles of association of e.g. Dutch financial institutions}

Dutch companies have defined their social responsibility in the articles of association. They all did this in various ways reflecting the organisation's specific character.

The ING Group, the largest financial service organisation of The Netherlands with a balance sheet value of approx. 830 billion Euros has laid down its objective in the Foundation for ING Continuity. This foundation issues depositary receipts of shares. When the continuity of the company is endangered, for instance in case of a hostile takeover, she can issue additional shares to protect the company. This broad social objective, legally necessary in the Netherlands to establish anti-takeover measures, is also found in article 3, section A:

The promotion of the interests of the holders of (depositary receipts of) shares (....) of the ING Group N.V. (....) also with consideration for the interests of
(I) the company itself (II) the interests of companies that are operated by the company and the companies that are affiliated with the company in a group (III) the interests of all other parties affiliated with the company in such a way that all of these interests will be weighed and preserved as well as possible.

ABN AMRO Holding N.V., a bank with a balance sheet total of over 560 billion Euros, has defined the broad social objective in the articles of association, article 2. lid 3:

The promotion of the direct and indirect interests of all parties that in any way are involved in the company, as well as of the company's continuity and the continuity of the companies affiliated with it.

The company interest may also be emphatically formulated for a single stakeholder group. The Rabobank Group (balance sheet total 403 billion Euros), has a cooperative association. This is emphatically a member objective. In Article 2, section 1 of the articles of association it says:

The objective of Rabobank Nederland is the promotion of the interests of its members.

The social role may also be formulated quite specifically, as is the case with the Triodos Bank N.V. This niche player (balance sheet total 800 million Euros) focuses on and invests in projects characterised by a social or an environmental objective. Article 2, section 2 of the articles of association states:

With the operation of the bank, the company strives to make a contribution to social innovation on the basis that any human being should be able to develop in freedom whilst having equal rights and being responsible for the consequences of his or her economic actions for his fellow human being and the earth, all in the widest sense of the word.

\section{References}

Ackerman, R. W.: 1973, 'How Companies Respond to Social Demands', Harvard Business Review 51(4), 8898.

Bauer, R. A. and R. W. Ackerman: 1976, Corporate Social Responsiveness: The Modern Dilemma (Reston Publishing Company, Reston).. 
Berman, S. and T. Rowley: 2000, 'A Brand New Brand of Corporate Social Performance', Business and Society 39(4), 397-418.

Bovens, M. A. P.: 1998, The Quest for Responsibility (Cambridge University Press, Cambridge).

Caldwell, C. and R. Karri: 2005, 'Organizational Governance and Ethical Systems: A Convenantal Approach of Building Trust', Journal of Business Ethics 58, 249-259.

Carrol, A. B.: 1979, 'A Three-Dimensional Conceptual Model of Corporate Social Performance', Academy of Management Review 4, 497-505.

Coffey, B. S. and J. Wang: 1998, 'Board Diversity and Managerial Control as Predictors of Corporate Social Performance', Journal of Business Ethics 17, 1593-1603.

Daboub, A. J. and J. M. Calton: 2002, 'Stakeholder Learning Dialogues: How to Preserve Ethical Responsibility in Networks', Journal of Business Ethics 41, 81-98.

Davis, J. H., F. D. Schoorman and F. David: 1997, 'Toward a Stewardship Theory of the Firm', Academy of Management Review 22(1), 20-47.

Freeman, R. E. and D. Reed: 1993, 'Stockholders and Stakeholders: A New Perspective on Corporate Governance', California Management Review 25(3), 88106.

Frooman, J.: 1999, 'Stakeholder Influence Strategies', Academy of Management Review 24(2), 191-205.

Gargiulo, M.: 1993, 'Two-Step Leverage: Managing Constraint in Organizational Politics', Administrative Science Quarterly 38(1), 1-19.

Grandori, A.: 1997, 'Governance Structures, Coordination Mechanisms and Cognitive Models', Journal of Management and Governance 1, 29-47.

Griffin, J. J.: 2000, 'Corporate Social Performance, Research Directions for the 21st Century', Business and Society 39(4), 479-491.

Heath, J. and W. Norman: 2004, 'Stakeholder Theory, Corporate Governance and Public Management: What can the History of State-Run Enterprises Teach Us in the Post-Enron era?', Journal of Business Ethics 53, 247-265.

Hillman, A. J., G. D. Keim and R. A. Luce: 2001, 'Board Composition and Stakeholder Performance: Do Stakeholder Directors Make a Difference?', Business and Society 40(3), 295-315.

Kochan, T. A. and S. A. Rubinstein: 2000, 'Toward a Stakeholder Theory of the Firm: The Saturn Partnership', Organization Science 11(4), 367-386.

Leader, S.: 1999, 'Participation and Property Rights', Journal of Business Ethics 21, 97-109.
Luoma, P. and J. Goodstein: 1999, 'Stakeholders and Corporate Boards: Institutional Influences on Board Composition and Structure', Academy of Management Journal 42(5), 553-564.

Margolis, J. D. and J. P. Walsh: 2003, 'Misery Loves Companies', Administrative Science Quarterly 48, 268-305.

Moerland, P. W.: 1995, 'Alternative Disciplinary Mechanisms in Different Corporate Systems', Journal of Economic Behavior and Organization 26, 17-34.

Nooteboom, B.: 1999, 'Voice- and Exit-Based Forms of Corporate Control: Anglo-American, European, and Japanese', Journal of Economic Issues XXXIII(4), 845860.

Sociaal-Economische Raad: 2000, De Winst van waarden, Den Haag.

Swanson, D. L.: 1995, 'Addressing a Theoretical Problem by Reorienting the Corporate Social Performance Model', Academy of Management Review 20(1), 43-64.

Swanson, D. L.: 1999, 'Toward an Integrative Theory of Business and Society: A Research Strategy for Corporate Social Performance', Academy of Management Review 24(3), 506-521.

Wartick, S. L. and P. L. Cochran: 1985, ,The Evolution of the Corporate Social Performance Model', Academy of Management Review 10(4), 758-769.

Weimer, J. and J. Pape: 1999, 'Corporate Governance', $A$ Taxonomy of Systems of Corporate Governance 7(2), 152166.

Whitley, R.: 1999, Divergent Capitalisms, The Social Structuring and Change of Business Systems (Oxford University Press, Oxford).

Williamson, O. E.: 2000, 'The New Institutional Economics: Taking Stock, Looking Ahead', Journal of Economic Literature 38(3), 595-613.

Wood, D. J.: 1991, 'Corporate Social Performance Revisited', Academy of Management Review 16(4), 691718.

Zadek, S.: 1998, 'Balancing Performance, Ethics, and Accountability', Journal of Business Ethics 17, 14211441.

Frank J. de Graaf and Cor A. J. Herkströter Corporate Responsibility Foundation, University of Amsterdam, Amsterdam Business School, Roetersstraat 11, $1018 \mathrm{WB}$, Amsterdam, Netherlands E-mail:F.J.deGraaf@uva.nl 